\title{
Fierce Literary Works of Kazi Nazrul Islam: A Rebellious Identity in the Domain of Bangla Literature
}

\author{
Farhana Haque, M.A \\ Department of English and Humanities \\ Brac University, Mohakhali, Dhaka, Bangladesh \\ dhak_121@yahoo.com
}

\begin{abstract}
As a perennial author Kazi Nazrul Islam upholds the title of 'Rebel poet' in Bangla literature as well as in world literature. Being a Muslim musician, poet and novelist, he used his poetry to inspire Indians to rebel against British colonialism. Thus is the proof of Nazrul's inflammatory attitudes against oppression. He had several pieces of literature banned by the British government in an attempt to supress the rebellious movements. Bidrohi is one of his famous anti British writing piece, which has immediately placed him in the public eye. In the time of rebellion and political unrest, Nazrul's poetry played a crucial role in uniting the oppressed and providing them with an intense sense of nationalism. He joined Swadeshi (self rule) and boycotts British He has composed many songs to sing and let the youths to become enthusiastic for ingrained nationalism, patriotism. His literary works were very much against the foreign rule, communalism, imperialism, colonialism, fundamentalism and exploitation. British government prescribed his books and put him behind bars. Through his written Rajbandir jibanbondi (prisoner's deposition) and his forty days hunger strike, Nazrul protested against the harassment. His writings were full of revolutionary messages that stirred up the spirit of freedom amongnest the grass roots level foiling masses. This made the British government cautious about Nazrul. This paper is an effort to understand the fierce works of Kazi Nazrul Islam, including some of his famous poems, songs, essays and anthologies.
\end{abstract}

Keywords: Kazi Nazrul Islam, Poetry, Literature, Song, Anthology, Colonialism, Rebellion

\section{INTRODUCTION}

Kazi Nazrul Islam is known as the national poet of Bangladesh. He has brought about the revolutionary changes in the spirit and style of Bangla literature and music. Nazrul was belongs to the $19^{\text {th }}$ century as a poet and musician. Eventually he became the national poet of Bangladesh and revolutionized the style of Bangla music and literature. He was imprisoned for his anti British writing. He wrote many poems and articles to support the struggle against the British. He wrote against the injustice, the oppression, the exploitation and the violence that was carried out all over India. Kazi Nazrul Islam was concerned about the landless farmers and workers and fought against social injustice through his writings. In this matter he was influenced by the socialist revolution in Russian that took place in 1971.

Kazi Nazrul Islam is the writer known for many literary pieces such as Bidrohi, (The Rebel). This poem was first published in 1921, thus it has been created the fierce reputation about Kazi Nazrul Islam. Following to his poem Bidrohi, he has written many more revolutionary poems, songs, and short stories. Therefore, Kazi Nazrul Islam's, poems, songs, anthologies are the incredibly important and significant concoctation to explore his fierce literary works in Bangla literature.

\section{Definition of Poetry in the Context of Nazrul's Poetry}

Poetry is the reflection of human's emotion and to hold its predisposition in front of the ethereal world. According to Words Worth, "Poetry is the spontaneous overflow of powerful feelings, where emotions recollect its tranquillity". These lines are thoroughly apt in the context of Kazi Nazrul Islam. His remarkable traits has been shown by his famous revolutionary poems. The Bengali National poet Kazi Nazrul Islam not only a poet to uplift the youth and general people against the oppression but also a man of absolutely iconoclastic attitudes. Cleanth Brooks argued, "Poetry is a unique kind of experience, which can never be capture in the kind of discursive description which constitutes a ' heresy of paraphrase'. Poetry is redemptive, in that it returns to us a more refractory 
original world, an ontologically distinct experience which offers a simulacrum of experiential fullness in the world outside of the text". (Brook, 22)

The ingenious words of Brooks incline to explore the phenomenal traits of Kazi Nazrul Islam. His poetry is the basic root of his impetuous rebellion. The stubborn attitudes towards nationalism and patriotism made him redemptive and thus he returned towards the victory of humanity and the establishment of justice. Outside of his texts he has manifested as a man of distinct characteristics which is the simulacrum of rebellious nature. Mill has declared that 'poetry' when it is really such, is truth; and fiction also, if it is good for anything, is truth: but they are different truths. The truth of poetry is to paint the human soul truly; the truth of fiction is to give a true picture of life. (67). Through the words of Mil it is also pertinent for the literary writings of Kazi Nazrul Islam. Kabi Nazrul expressed the truth of life through his magnificent poems of love, poverty, rebellion, right for women etc. He has portyed the clear picture of society and aimed to construct a better society and as a whole a better world.

\section{THE EARLY LIFE OF KAZI NAZRUL ISLAM}

From the beginning of Nazrul's life, he was in intense adverse condition. Throughout his life he was grown up as a boy of struggle, injustice, agonies and pains, thus he was known as 'Dukhu Mia (Sorrowful man). He was born in a poor Muslim family, where he only received religious education. To run his poor life and his family, the young boy Nazrul had to work as a Muezzin in a local Mosque. Though he was staying in a sorrowful condition but his inherent poetic fire was still burning in his heart, that is why he didn't let him shatter completely and dreamt to access the realm of literature. Nazrul had great love for literature and was keen to learn it and make it as his passion. Later on in his life, God has given him such talents to establish his name in the genre of literature. And he got the scope to learn all the branches of literature i.e. poetry, drama, when he was appeared as a member in some of the theatrical groups and in the time of working with them, he was fascinated by different kinds of knowledgeable things and tried to acquire those things in his journey towards literature. In the early life Nazrul also served in the British as Indian army but being led by the revolutionary thoughts, he left the British army and joined the press in Calcutta as a journalist to express and spread his ideologies about nationalism, patriotism for his country.

\section{Kazi Nazrul Islam as a Poineer Rebel Poet in Bangla literature}

Kazi Nazrul Islam has established his existence as a pioneer Rebel poet in Bangla literature. Most of his literary works are based on revolution. His has espoused the stream of fierce literary works. Because of his revolutionary poetry and national activism, he was given the title "Rebel poet" by the people. And being a Bengali, he was known as Bidrohi Kabi (Rebel Poet). In the field of Bengali literature Kabi Nazrul paved his way as a poet of wrath against all the oppression, injustice, exploitation over the innocent Bengali in India.

\section{KAZI NAZUL'S DISDAIN ABOUT THE BRITISH RAJ}

Being a man of revolution, Nazrul had the intense hatred towards the establishment of British Raj in India. Through his poetic works like Bidrohi ( The Rebel), Bhangar Gaan ( The song of Destruction) and his famous publication Dhumketu ( The Comet), he showed the tireless endeavour to attack the British government in India. His aim was to free his country from the grip of British colonialism. To accomplish his goal, he had to set up his mind towards the deeds of revolution and patriotism, therefore he had to face the hurdles which led him imprisoned many times by the British authorities. After staying in prison he kept the continuation of his fierce writings. He wrote Rajbandir Jabanbandi (Disposition of a Political Prisoner). All of his revolutionary writing pieces made him not only a freedom fighter but also a man of truth, who did work to free the subaltern group and down trodden people from the illusion of British rule.

\section{KAZI NAZRUL'S ASSOCIATION WITH THE TERM 'FOLK'}

Kazi Nazrul Islam was associated with folk theatre group named Helo. It was successfully run by his uncle and this was the striking point of Nazrul's love for literary things. As Nazrul was associated with the folk group, he learned how to act, sing songs and wrote poems for his group. Inspired by the theatre he learned Hindu Scriptures such as Purans with Bengali and Sanskrit literature. For his group, he composed many plays such as Chasar San (The Story of a Farmer), Shakunibandh ( The killing of 
a vulture), Raja Yudhistir San ( The Story of Yudhistir), Data Korna ( Philanthropic Karna), Akbar Badsha ( Emperor Akbar), Kavi Kalidas ( Poet Kalidas), Vidyabhutam ( The Learned Owl), and Rajputer San ( The Story of a Prince).

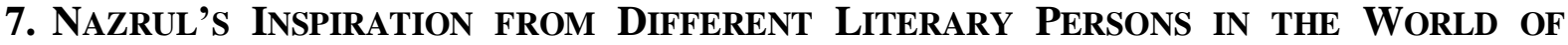 LITERATURE}

Kazi Nazrul Islam was deeply influenced by some of the prominent figures in Literature. Rabindranath Tagor was one of the influential writer for Nazrul. Being a Bengali, Nazrul was very much attracted by the magical writings of Rabindranath Tagor. He was also fascinated by the other creative icons of Bengali literature, such as Saratchandra Chattopadhyay. After coming out from Bengali literature, Nazrul was enthralled by the Persian poets and their remarkable writing pieces. Nazrul expressed his utmost praiseworthy words for Hafiz, the phenomenon poet, Rumi, the poet of aesthetic beauty, and Omar Khayyam, the vehement poet. Under their influence he has used Persian vocabulary in his writings which made the demarcation line of his writings even more wider.

\section{REMERKABLE LITERARY WORKS OF KAZI NAZRUL ISLAM}

Kazi Nazrul Islam's literary works began with the publication of his prose work, Baunduler Atmakahini (Life of a Vagabond) in May 1919. Following the same year in July, Nazrul was accomplished his another poem Mukti (Freedom) published in Mussalman Sahitya Patrica. In 1922, this poem was published with the publication "Bidrohi" (The Rebel) which made him famous and perennial rebel poet. Bidrohi was one of the greatest poem in Bengali literature, where the elements of revolution was the consolidate subject. In the epoch of Nazrul, he was created a irrevocable situation of revolution against all kinds of oppression. The writing pieces of Nazrul were based with fierce words which have been exhibited in his poems. Some famous lines from Bidrohi has been smashed the readers forever.

I am the unutterable grief

I am the throbbing ten

I am the wild fire on the woods,

I am Hell's mad terrific sea of wrath!

I ride on the wings of lightening with joy and profundity,

I scatter misery and fear all around,

I will bring earth-quakes on this world! " $\left(8^{\text {th }}\right.$ stanza $)$

Weary of struggles, I the great rebel,

Shall rest in quiet only when I find

The sky and the air free of piteous groans of the

Only when the battle fields are cleared of jingling bloody sabres

Shall I, weary of struggles, rest in quiet,

I am the rebel eternal,

I raise my head beyond this world and,

High, ever erect and alone! "(Last stanza)"

The above lines denotes the depth of Nazrul's rebellious nature. This poem was actually written after seeing the circumstances of his motherland. And according to the need of the country he wrote such an fierce poem. When India was under British rule and the people wanted to get rid from their grips. To inspire them Nazrul tried to motivate them through his writings. These eternally ingrained lines for revolution, made the Rebel poet became an extra ordinary poet who came out from the contemporary poets of his time. Nazrul was not only a poet of rebellious nature but also famous for his rebellious language which he has been used in his poems drastically.

The poem Bidrohi was published in the magazine "Bijli" (Thunder) in the year 1922. In the time when Gandhi ji started the non-cooperation movement to throw the British empire from India, immediately on that time Nazrul's poem Bidrohi made the general people brave and enthusiastic for eradicate the root of British Raj. After portraying Nazrul's poems with aesthetic beauty and universal appeal towards sensivity, he has also started to portrayed his first anthologies of poems Agniveena 
(The Lyre of Fire) in 1922. Nazrul got success in other genre of literature i.e. short stories, prose work and essays. He published his first volume of short stories, the Byather Dan (Gift of sorrow) and Yugbani, an anthology of essay in 1922.

\section{Justice in Social, And Political Sectors in Nazrul's W RitingS}

Kazi Nazrul Islam, was very much active against all sorts of injustice roaming in the society's threshold. Through literature, journalism and political activism, Nazrul fought against the British colonialism, fundamentalism, communalism, society's prejudice and injustice towards poor people, women and the outlawed people. The British government raided his books and newspaper and put him behind the prison. But Nazrul didn't stop his revolutionary activities and has written Rajbandir Jabanbandi ( A Political Prisoner's disposition). After that he took 40 days hunger strike for protesting against the harassment. Besides the image of being a revolutionary poet, Nazrul was very much concerned about social injustice by the rich people. He was sad after seeing the issue of poverty in his society. He had a deep contemplation regarding the people who was facing poverty and misery. Thus, all these significant affairs got reflected in his writings. Daridro (Pain or Poverty) is one of the social awakening poem, where Nazrul had depicted his pain for the people of his country.

O poverty, thous hast made me great,

Thou hast made me honoured like Christ

With his crown of thorns. Thou hast given me

Courage to reveal all. To thee I owe

My insolent, naked eyes and sharp tongue.

Thy cursed has turned my violin to a sword...

O proud saint, thy terrible fire

Has rendered my heaven barren

O my child, my darling one

I could not give thee even a drop of milk

No right have I rejoice.

Poverty weeps within my doors forever

As my spouse and my child

Who will play the flute.

This poem has incredibly carried the social message, and the profound love and concern for the people of his country. Like this poem, Nazrul has written another significant poem on women's right and showed his proper respect to them. Nari (Women) is one of the effective poem to show the respect and his thoughts to establish the parity between men and women's right.

I don't see any difference

Between a man and a woman

Whatever great or benevolent

That are in this world achievements

Half of that was by a woman

The other half by man.

These lines about women's respect clearly shows that, Nazrul was not confined within the men's world and their affairs, he was also concerned about women's right with due respect. Nazrul utterly believed that Women also need to have the same right as the men's world is getting. This was more than a revolutionary thought at that time when women were considered as a petty human being who will only work inside of the house, give birth of her children and care for her husband. This is what the marginalised women used to do in that time. Nazrul tried to uplift their spirit and boosted them up about life. Birangona (Prostitute) is another poem of efficacy where Nazrul made the Birangona 
women as a nexus of women who were worthy for praiseworthy words and proper respect in society by telling them 'mother'. By this unprecedented statement for Birangona, there was arrived a storm of criticism in society. Nazrul's ideologies were different than the other contemporary writers. He considered that every women should be respected whether if she is a prostitute. His ideologies were relevant as he remarked that, circumstances are responsible to make them prostitute. As nobody is a born spoiler such as murderer, so in the same way no woman is born as prostitute. Nazrul's fierce writings poured like assailed towards society's negative concepts about prostitute. His thoughts were appropriate regarding prostitute and he has placed that instance to the world. Nazrul's respect for prostitute was reflected through his poem Birangona. He says:

Who calls you a prostitute, mother?

Who spits at you?

Perhaps you were suckled by someone

As chaste as seeta...

And if the son of an u chaste mother is 'illegitimate'

So is the son of an unchaste father.

This is the way of Nazrul's respect and compassion towards the group called prostitute. He was surely an advocate of the emancipation of women, which was clearly expressed through his poem.

\section{Parity in Every Religion Emerge as the Rebellious Notion in Nazrul's WRITINGS}

Religious issue was one of the prominent issue in Nazrul's writings. This issue became prevail over other issues in his later part of life. Kazi Nazrul Islam appeared as an another writer in order to express his parity in every religion. He made a mixture of Islamic devotional songs with the Bengali folk music. This was the outstanding creation of Nazrul which was helpful to take him towards more achievements. Besides the Islamic devotional songs with Bengali folk music, Nazrul looked for Hindu devotional music. Such as Shama Sanget, Bhajan and Kirtans. He has synthesized Islamic and Hindu values. This fusion was the ideologies of Nazrul, which he has made with both the Islam and Hinduism. He did not like fanatism and always fought for Hindu -Muslim unity. Kabi Nazrul expressed his devotional writings so detail, therefore he exhibited his perspectives of religious harmony in an editorial Joog Bani,

Come brother Hindu! Come Musalman! Come Buddhist!

Come Christian! Let us transcend all barriers, let us forsake

Forever all smallness, all lies, all selfishness and let us fall

Brothers as brothers. We shall quarrel no more.

By these very crystalline words, its is to be noted that, Nazrul is not only a poet but also a true humanist. He proved his religious equality by choosing his four sons names with both Hindu and Muslim names. His first son was named by Krishna Muhammad, then Arindam Khaled (Bulbul), after that Sabyasachi and at last his fourth son named by Kazi Aniruddha. Nazrul was deeply plunged in a tradition of Hinduism, Sufism, folk tradition to make his doctrine in a uprising way.

\section{KAZI NAZRUl ISLAM's Enriched Literary WORKS IN Front OF THE WorLd LITERATURE}

In the writings of Nazrul, he was ingenious to express his love, freedom and revolution. In his innate nature he was open minded, didn't allow any kinds of prejudice based on gender, class, caste and religion. He was a liberal person and opposed to the realm of anarachy. As a writer he tried his best to portray all of his insight understanding related life. He was an innovator in the literary field. Nazrul did present many famous poems, songs, short stories, essays and also he has brought Bengali Ghazals which was the brand new segment in Bengali literature. He was a composer of 4,000 songs which are known as Nazrul Geeti. For his phenomenal Nazrul Sangit, Nazrul was and still now he is famous in India and Bangladesh. Everyone remembers his name with pride and respect. In the form of World literature Kazi Nazrul Islam has contributed immensely. He was considered as the epitome of Bangla 
poetry and other literary works. Nazrul was the inspiration to the world and still his works are truly inspiring towards all kinds of persons, and in all time zone. In the future his fierce writing pieces would keep us enthralled not only in the Bengali literature but the world of literature as well.

\section{CONCLUSION}

Kazi Nazrul Islam, the national poet of Bangladesh and also known as the 'Rebel poet' not only in Bangladesh but also in front of the whole world. His fierce resistance towards all forms of oppression, injustice, has been expressed enormously by his poems, short stories, songs and essays. Nazrul has created the vibrant rhythms and iconoclastic themes, formed a revolutionary and drool worthy contrast to the contemporary poets. His use of vocabulary and subjects were never been happened in the history of Bangka poetry before. He became immensely popular for portraying his poems with the issues of political and social matters. Nazrul was also known as a poet of unprecedented activities such as the fusion of Hindu and Muslim cultural traditions. In the field of mixing the Bangla metres with Arabic and Sanskrit, Nazrul was the master for doing that. Nazrul nourished almost all the streams of Bangla literature and generated the solid foundation in the history of world literature.

\section{REFERENCES}

[1] Abdul Hakim, The Fiery Lyre of Nazrul Islam (Bangla Academy, Dhaka, 1976)

[2] Brooks, Cleanth. "The Well Wrought Urn". Leitch 1353-1366.

[3] J.S. Mill, 'Thought on Poetry and its Varieties', in Dissertations and Discussion, Politics, Philosophy and History, i ( London: J.W Parker and son, 1859)

[4] Karunamaya Goswami, Kazi Nazrul Islam: A Biography, ( Nazrul Institute; 1996)

[5] Moniruzzaman, Mohammad, "Interaction of cultures and Kazi Nazrul Islam". In Mohammad Nurul Huda, Nazrul: An Evaluation. (Dhaka: National Institute. 2000).

[6] Priti Kumar Mitra, The Dissent of Nazrul Islam: poetry and History ( New Delhi, OUP India, 2009)

[7] Rafiqul Islam, Kazi Nazrul Islam: An Anthology, (Bangla Academy; Dhaka, 1990)

[8] Huda, Muhammad Nurul (2001). Nazrul's Aesthetics and other aspects. Nazrul Institute. P. 129.

\section{AUTHOR's BIOGRAPHY}

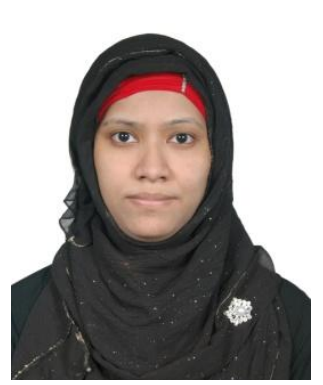

Farhana Haque, was born in Dhaka, Bangladesh in 1989. She has been completed her Master Degree in English from Brac University. Nationally she has been published two poem books and Research Papers in International Journals. Her research interests include: Colonialism, Anti Colonialism, Feminism, Poetry analysis of different authors of different eras, Western authors and Eastern authors Biography analysis, exploration of Novels based on different subject matters. 